\title{
The effects of water and sucrose contents on the physicochemical properties of non-directly expanded rice flour extrudates
}

\author{
Os efeitos do teor de água e de sacarose nas propriedades \\ físico-químicas de extrusados não expandidos de arroz \\ Marcia Cristina da SILVA ${ }^{1}$, Carlos Wanderlei Piler de CARVALHO ${ }^{2}$, Cristina Tristão ANDRADE ${ }^{3 *}$
}

\begin{abstract}
Rice flour was processed by extrusion cooking in the presence of variable contents of water and sucrose. The process was carried out in a twin-screw extruder under the conditions given by a centre rotational experimental design of second order. The effects of the independent variables, water content (27.9 to $42.1 \%)$, and sucrose content $(0.1$ to $19.9 \%)$ on the physicochemical properties of the extrudates were investigated. The water absorption index (WAI), water solubility index (WSI), volumetric expansion index (VEI), and bulk density (BD) were determined as dependent variables. BD was determined for samples before and after frying. An increase in water contents resulted in higher WAI and VEI, and lower WSI and BD for extrudates before and after frying. Higher sucrose levels led to increased values of WAI and VEI and to reduced values of WSI and BD. Both independent variables had significant influence on the physicochemical properties of rice flour extrudates. However, the sucrose content was the most significant. The interaction between these two independent variables and their quadratic effect were also important for the responses studied.
\end{abstract}

Keywords: Orysa sativa L.; sugar; extrusion; water absorption index; water solubility index; volumetric expansion index; bulk density.

\section{Resumo}

A farinha de arroz foi extrusada em presença de diferentes teores de água e sacarose. O processamento foi realizado em extrusora duplarosca, sob condições fornecidas por um delineamento experimental rotacional de segunda ordem. Os efeitos das variáveis independentes, teor de água (27,9 a 42,1\%) e teor de sacarose (0,1 a 19,9\%), sobre as propriedades físico-químicas dos extrusados, foram estudados. As variáveis dependentes avaliadas foram o índice de absorção de água (WAI), o índice de solubilidade em água (WSI), o índice de expansão volumétrica (VEI) e a densidade aparente (BD). A densidade aparente (BD) foi determinada para os extrusados antes e depois do processo de fritura. $\mathrm{O}$ aumento no teor de água resultou em maiores valores de WAI e VEI e menores valores de WSI e de BD (para as amostras fritas e não fritas). Os maiores teores de sacarose levaram a altos valores de WAI e VEI, e valores reduzidos de WSI e de BD (para as amostras fritas e não fritas). Ambas as variáveis independentes influenciaram, significativamente, as propriedades físico-químicas de extrusados de farinha de arroz. No entanto, o teor de sacarose foi a variável mais significativa. Os efeitos quadráticos, bem como a interação entre as duas variáveis independentes, também foram importantes para as variáveis das respostas estudadas.

Palavras-chave: Orysa sativa L.; açúcar; extrusão; índice de absorção de água; índice de solubilidade em água; índice de expansão volumétrica; densidade aparente.

\section{Introduction}

Rice (Orysa sativa L.) is one of the most important staple foods for people in many countries, especially in Asia. Recently, rice has become an attractive raw material for the manufacture of new cereal foods including rice beads and rice products for frying (KADAN et al., 2001). Rice flour has been used as an ingredient in the food industry because of its unique attributes, such as bland taste, white colour, hypoallergenicity, and easy digestion (BRYANT et al., 2001; KADAN; BRYANT; PEPPERMAN, 2003).

Extrusion cooking, as a continuous mixing, cooking, and forming process, is a versatile, low cost, and very efficient technology in food processing. During extrusion cooking, starch raw materials undergo many chemical and structural transformations, such as starch gelatinisation, protein denaturation, complex formation between amylose and lipids, and degradation of vitamins, pigments, etc (ILO; BERGHOFER, 1999). Despite the increasing use of extrusion process, it still has to be mastered due to its complexity. Small variations in processing conditions affect response variables, as well as the quality of final products (DESRUMAUX; BOUVIER; BURRI, 1999).

The extent of physical and chemical changes in the extrusion processing depends on the type of starch, presence of other constituents such as sugars, moisture content, feed rate, residence

Recebido para publicação em 28/1/2008

Aceito para publicação em 3/1/2009 (003181)

${ }^{1}$ Departamento de Bioquímica, Instituto de Química, Universidade Federal do Rio de Janeiro - UFRJ, CEP 21949-900, Rio de Janeiro - RJ, Brasil

${ }^{2}$ Embrapa Agroindústria de Alimentos, Laboratório de Extrusão e Reologia de Alimentos, CEP 23020-470, Rio de Janeiro - RJ, Brasil

3 Centro de Tecnologia, Instituto de Macromoléculas Professora Eloisa Mano, Universidade Federal do Rio de Janeiro - UFRJ, CP 68525, CEP 22020-002, Rio de Janeiro - RJ, Brasil, E-mail: ctandrade@ima.ufrj.br

${ }^{*}$ A quem a correspondência deve ser enviada 
time inside the extruder, screw configuration, screw speed, and temperature profile (AKDOGAN, 1996). The moisture content is one of the most important variables in the extrusion processing of starches, and its effect has been studied by many authors in recent years. Ding et al. (2005) and Hagenimana, Ding and Fang (2006) studied the effects of moisture content on rice flour extrudates. Thymi et al. (2005) and Ding et al. (2006) evaluated the effect of the moisture content on maize and wheat starch extrudates, respectively. Moisture highly contributes to physical changes in the starch structure, such as gelatinisation, melting, and molecular degradation.

Sugar is often added to cereal-based products after the extrusion processing, before drying. The effect of sugars on the extrusion processing of starches has already been studied by some authors (BARRET et al., 1995; HSIEH; PENG; HUFF, 1990; HSIEH et al., 1993; MEZREB et al., 2006). However, these authors studied the addition of sugar at levels around $10 \%$. Higher sugar levels may lead to some important modifications in the quality of final products, an issue of interest to the food industry.

In the present work, the effects of moisture and sucrose contents on the physicochemical properties of rice flour extrudates, produced with a twin-screw extruder, were investigated.

\section{Materials and methods}

\subsection{Materials}

Broken rice was supplied by Josapar Beneficiadora de Arroz Ltda. (Pelotas, Brazil). Rice flour was obtained by milling broken rice in a disk mill (Perten Instruments model 3600, Huddinge, Switzerland). The composition of rice flour was determined as $77.1 \%$ carbohydrates (calculated by difference), $8.38 \%$ proteins, $0.65 \%$ fat, $0.52 \%$ ash, and $13.39 \%$ moisture. Commercial sucrose (Açúcar União, Rio de Janeiro, Brazil) from sugar cane was acquired from a local shop.

\subsection{Experimental design and statistical analysis}

A centre composite rotational experimental design of second order was used to plan composition variables, moisture and sucrose contents in twelve runs, six of which were for the combination of +1 and -1 levels, two for $+\alpha$ and $-\alpha$ levels, and four for the centre point. For each variable, extreme levels were established according to preliminary experiments. The other three levels were established in relation to those extreme levels. The five levels, coded $-\alpha,-1,0,+1$, and $+\alpha$, are shown in Table 1 together with their respective experimental values.

Table 1. Coded levels for the experimental design.

\begin{tabular}{lrrrrr}
\hline \multicolumn{1}{c}{ Independent variables } & \multicolumn{5}{c}{ Levels } \\
\cline { 2 - 6 } & \multicolumn{1}{c}{$-\alpha^{\mathrm{a}}$} & -1 & 0 & +1 & $+\alpha^{\mathrm{a}}$ \\
\hline Water content $^{\mathrm{b}}(\%), \mathrm{x}_{1}$ & 27.9 & 30 & 35 & 40 & 42.1 \\
Sucrose content $^{\mathrm{c}}(\%), \mathrm{x}_{2}$ & 0.1 & 3 & 10 & 17 & 19.9 \\
\hline
\end{tabular}

Where $\mathrm{x}_{1}=$ water content ( $\%$ w.b.) and $\mathrm{x}_{2}=$ sucrose content $\left(\%\right.$ of dry rice flour); ${ }^{\mathrm{a}} \alpha=1.414$;

${ }^{\mathrm{b}}$ water content (wet basis); and ${ }^{\mathrm{c}}$ sucrose content based on rice flour (dry basis).
The response surface methodology (RSM) was used to determine the effects of water and sucrose contents on extrusion and physicochemical properties of rice flour extrudates. The response functions were water absorption index (WAI), water solubility index (WSI), volumetric expansion index (VEI), bulk density (BD) of extrudates before and after frying. These five response functions were related to the variables of the extrusion process by a second-degree polynomial (Equation 1), which consisted of linear, quadratic, and interaction effects, and were computed by regression analysis using Statistica for Windows version 5 (Statsoft, Tulsa, USA).

$\mathrm{y}=\mathrm{B}_{\mathrm{o}}+\mathrm{B}_{1} \mathrm{x}_{1}+\mathrm{B}_{2} \mathrm{x}_{2}+\mathrm{B}_{11} \mathrm{x}_{1}{ }^{2}+\mathrm{B}_{22} \mathrm{x}_{2}^{2}+\mathrm{B}_{12} \mathrm{x}_{1} \mathrm{x}_{2}+\varepsilon$

where $y$ is response; $x_{1}$ refers to water content, $x_{2}$ refers to sucrose content, $\mathrm{B}_{\mathrm{o}}$ is the intercept; $\mathrm{B}_{1}$ and $\mathrm{B}_{2}$ represent linear effects; $\mathrm{B}_{11}$ and $\mathrm{B}_{22}$ represent quadratic effects; and $\mathrm{B}_{12}$ represents interaction effects. Analysis of variance (ANOVA) tables were generated for the response functions. The significance of the individual terms in the polynomial was determined statistically by judging them at probability levels up to $5 \%$ ( $\mathrm{p} \leq 0.05$ ). For each response, three-dimensional plots were produced from regression equations considering the two variables. For each graph, scales and the position of the axis were adapted for a better interpretation.

\subsection{Preparation of samples}

Rice flour/water/sucrose mixtures at different compositions were mixed in a planetary mixer and kept at $18{ }^{\circ} \mathrm{C}$ for 24 hours before extrusion processing.

\subsection{Extrusion of rice flour formulations}

Rice flour/water/sucrose mixtures at different compositions were manually fed and extruded in a Haake Rheocord 9000 System (Karlsruhe, Germany) fitted with co-rotating, intermeshing conical twin-screws (diameter of $22 \mathrm{~mm}$, and flat die) at a constant screw speed of $150 \mathrm{rpm}$. The extrusion temperature profile in the four heating zones was maintained constant at $70,100,90$, and $70{ }^{\circ} \mathrm{C}$ from feed zone to die end. After processing, the extrudates were allowed to cool, cut into pieces of $3 \mathrm{~cm}$ in length, and dried in a tray drier (Ética Indi-30, São Paulo, Brazil) at $50^{\circ} \mathrm{C}$ for about 10 hours. Some of the non-expanded extrudates were milled in a disk mill (Perten Instruments 3600, Huddinge, Switzerland) and, subsequently, in a roller mill (Brabender QU-J, Duisburg, Germany) for further analyses. Since the particle size distribution may affect the WAI and WSI results, the particle size of the milled extrudates was selected in the range of 100 to $250 \mathrm{~m} \mu$. The water content of powdered extrudates was determined by drying the samples in triplicate in a tray drier (Ética Indi-30, São Paulo, Brazil) at $105^{\circ} \mathrm{C}$ to constant weight.

\subsection{Water absorption index (WAI) and water solubility index (WSI)}

WAI and WSI were determined as described by Anderson et al. (1969) with modifications. To determine WAI, $1 \mathrm{~g}$ (starch dry basis and sucrose content correction) of each 
sample was suspended in $10 \mathrm{~mL}$ of distilled water at ambient temperature in a tared centrifuge tube. The suspension was stirred in a Vortex mixer for 1 minute, shaked for 30 minutes, and then centrifuged in a Hermle centrifuge, model Z383 (Labnet International, Inc., Woodbridge, USA) at $3500 \mathrm{rpm}$ for 10 minutes. The liquid supernatant was poured into a tared evaporating dish and dried at $110^{\circ} \mathrm{C}$ to constant weight. The weight of the remaining gel was taken as WAI, and expressed in $\mathrm{g} . \mathrm{g}^{-1}$. The amount of dried solids, recovered by evaporating the supernatant from the WAI analysis and expressed as percentage of dry solids, was taken as WSI. WAI and WSI determinations were made in quadruplicate.

\subsection{Volumetric expansion index (VEI)}

The dried non-expanded extrudates were fried in soybean oil at $200^{\circ} \mathrm{C}$. The excess of oil was soaked in paper. The volume of each extrudate sample before and after frying was measured by the methodology of displacement developed by Seker (2005). VEI was calculated by dividing the expanded (fried) volume by the non-expanded volume. The dimensions of ten randomly collected samples of each extrudate were measured with a pachymeter and an average was taken. Before frying, the water content of each sample was determined by drying the samples in triplicate in a tray drier (Ética Indi-30, São Paulo, Brazil) at $105^{\circ} \mathrm{C}$ to constant weight.

\subsection{Bulk density (BD)}

The BD was calculated for the extrudates before and after frying by dividing the weight of each sample by its volume. Ten randomly collected samples of each extrudate were measured and an average was taken.

\section{Results and discussion}

\subsection{Water absorption index (WAI)}

WAI measures the volume occupied by the starch after swelling in excess water (MASON; HOSENEY, 1986), which corresponds to the volume of the gel formed. WAI depends on the availability of hydrophilic groups and on the capacity of gel formation of the macromolecule (GOMEZ; AGUILERA, 1983). The effects of water and sucrose contents on WAI of rice flour extrudates are shown in the three-dimensional surface plot of Figure 1. The regression coefficients in Table 2 show that the positive linear effects of water and sucrose contents had the most significant influence $(\mathrm{p} \leq 0.001)$ on the WAI of extrudates. The quadratic effects of both water and sucrose contents were not significant $(p>0.05)$ for WAI. The interaction between the two independent variables was significant $(p \leq 0.01)$ and influenced negatively this response variable, as shown in Figure 1.

Experimental WAI values for the extrudates ranged between 3.15 and $4.91 \mathrm{~g} \cdot \mathrm{g}^{-1}$. The highest value found was 4.91 g.g $\mathrm{g}^{-1}$ for experiment 3 , which was processed at $40 \%$ water content and 3\% sucrose content. The lowest value found for this response variable $\left(3.15 \mathrm{~g}^{\mathrm{g}} \mathrm{g}^{-1}\right)$ was determined for experiment 2 , in which $30 \%$ water content and $17 \%$ sucrose

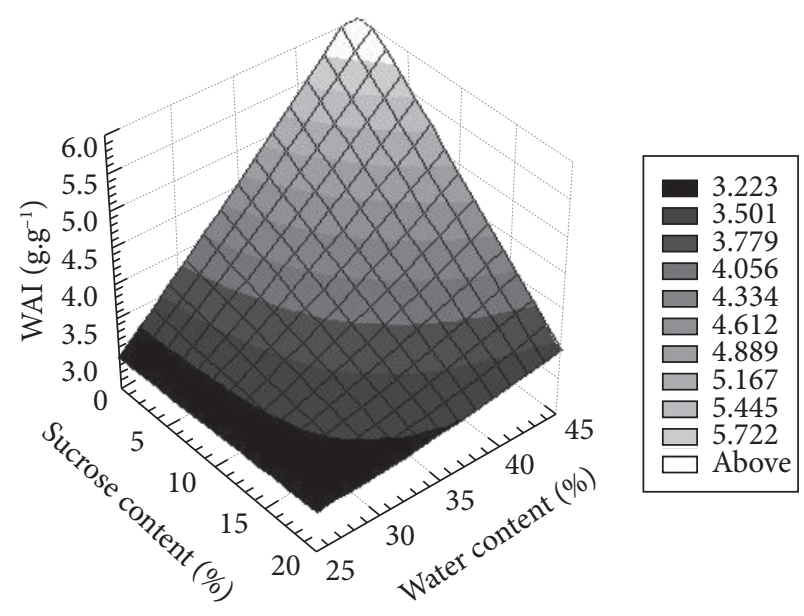

Figure 1. Effect of water and sucrose contents on the water absorption index (WAI) for rice extrudates.

content were used. Regarding the extrusion of oat, Singh and Smith (1997) reported that an increase in water content led to higher values of WAI. More recently, Ding et al. (2005) also found that increasing the feed moisture from 11.27 to $24.73 \%$ significantly increased the WAI of rice extrudates.

The conversion of raw starch into a cooked and digestible material, by the application of water and heat, is one of the important effects of extrusion (DING et al., 2005). The water content was found to exert the most important effect on the starch conversion during an extrusion process. The maximum starch conversion occurs at low water contents and high temperatures (HAGENIMANA; DING; FANG, 2006). The response surface plot of Figure 1, obtained from Equation 1, shows that the highest values of WAI were obtained for the highest values of water content. Water acts as a plasticiser in the extrusion of starch; it reduces degradation resulting in products with a higher capacity of water absorption. It is worth to note that starch granules should undergo a certain degree of conversion to initiate water absorption. Native starch can only absorb a minimum amount of water (GUHUA; ALI; BHATTACHARYA, 1997). In the present work, the extrusion of rice flour at water contents lower than $30 \%$ led to reduced WAI values. This result may indicate that under these conditions starch molecules were degraded. Those degraded molecules have low water absorbing capacity.

At low water contents, in the range of 25 to $27 \%$, no increase in WAI was observed with the increase in the sucrose content. In contrast, at higher levels of water, the decrease in the sucrose content led to increased WAI values. The highest experimental \left. value of WAI ( $4.9{\mathrm{~g} . \mathrm{g}^{-1}}^{-}\right)$was observed at low sucrose content and high water content. The increase in sucrose led to the decrease of WAI values. This result is in agreement with the data of Mezreb et al. (2006), who worked with maize and wheat. For maize extrudates, the same authors observed a sharp reduction of WAI as sucrose content increased. However, this behaviour was not observed for wheat extrudates. 
Table 2. Regression and correlation coefficients of the response variables.

\begin{tabular}{cccccc}
\hline Coefficients & WAI & WSI & VEI & BD (before frying) & BD (after frying) \\
\hline $\mathrm{B}_{0}$ & -0.4477 & 69.8091 & -1.5254 & 1.1944 & 0.5183 \\
$\mathrm{~B}_{1}$ & $0.1195^{* * *}$ & $-3.0581^{* *}$ & 0.3171 & $-0.0128^{*}$ & -0.0172 \\
$\mathrm{~B}_{2}$ & $0.1927^{* * *}$ & $-0.6941^{* *}$ & $0.1431^{* * *}$ & $-0.0083^{* * *}$ & $-0.0059^{* * *}$ \\
$\mathrm{~B}_{11}$ & 0.0007 & $0.0379^{* *}$ & $-0.0042^{* *}$ & $0.0002^{* *}$ & $0.0002^{* * *}$ \\
$\mathrm{~B}_{22}$ & 0.0000 & 0.0145 & $-0.0040^{* * *}$ & $0.0003^{* * *}$ & $0.0002^{* * *}$ \\
$\mathrm{~B}_{12}$ & $-0.0074^{* *}$ & $0.0165^{*}$ & $-0.0024^{* *}$ & $0.0001^{*}$ & $0.0001^{* *}$ \\
$\mathrm{R}^{2}$ & 0.92 & 0.80 & 0.70 & 0.71 & 0.73 \\
\hline
\end{tabular}

***Significant at the $0.1 \%$ level; ${ }^{* *}$ significant at the $1 \%$ level; and ${ }^{*}$ significant at the $5 \%$ level.

\subsection{Water solubility index (WSI)}

WSI is related to the amount of soluble solids, which is often used as an indication of degradation of starch molecules, and dextrinisation (GUHUA; ALI; BHATTACHARYA, 1997; DOGAN; KARWE, 2003). It can also measure the degree of starch conversion during extrusion, which corresponds to the amount of soluble polysaccharide released from the starch granule (DING et al., 2005).

As shown in Table 2, WSI was mostly influenced by the negative linear effects of water and sucrose contents $(\mathrm{p} \leq 0.01)$ followed by the positive quadratic effect of the water content $(p \leq 0.01)$. The interaction between the two independent variables had a positive linear effect $(\mathrm{p} \leq 0.05)$ on WSI of rice flour extrudates. The highest WSI value, $14.4 \%$, was found for the experiment carried out with $30 \%$ water and $17 \%$ sucrose; whereas the lowest WSI value, $8.5 \%$, was determined for the experiment with $40 \%$ water and $3 \%$ sucrose.

Figure 2 shows the effects of water and sucrose contents on WSI for rice flour extrudates. An increase in WSI was observed with decreasing amounts of water, which is consistent with the results reported by Ding et al. (2005) on rice flour extrusion at water contents varying from 11.27 to $24.73 \%$, and by Hagenimana, Ding and Fang (2006) on rice flour extrusion at water contents between 16 and 22\%. Extrusion at low water contents would cause an increase in the amount of water soluble molecules.

According to the model proposed by Gomez and Aguilera (1984), three types of starch (raw, gelatinized, and dextrinised) may be found in extruded products. Due to those different starch types, some samples may not be completely converted, whereas some others may be over-processed or dextrinised.

Regarding the effects of the sucrose content, the lowest levels of sucrose led to the lowest WSI values. This effect was observed for water contents higher than 35\%. Carvalho and Mitchell (2001) suggesting that sugars may reduce the starch conversion through two mechanisms: an increase in the melting temperature and a reduction in the specific mechanical energy. Nevertheless, because of their low molecular weight, the addition of sugars tends to increase the content of soluble solids.

In addition to the formation of dextrinised starch during extrusion, molecular interactions between degraded starch, protein, and lipid components may decrease the solubility and, consequently, WSI. Although these phenomena may hold true,

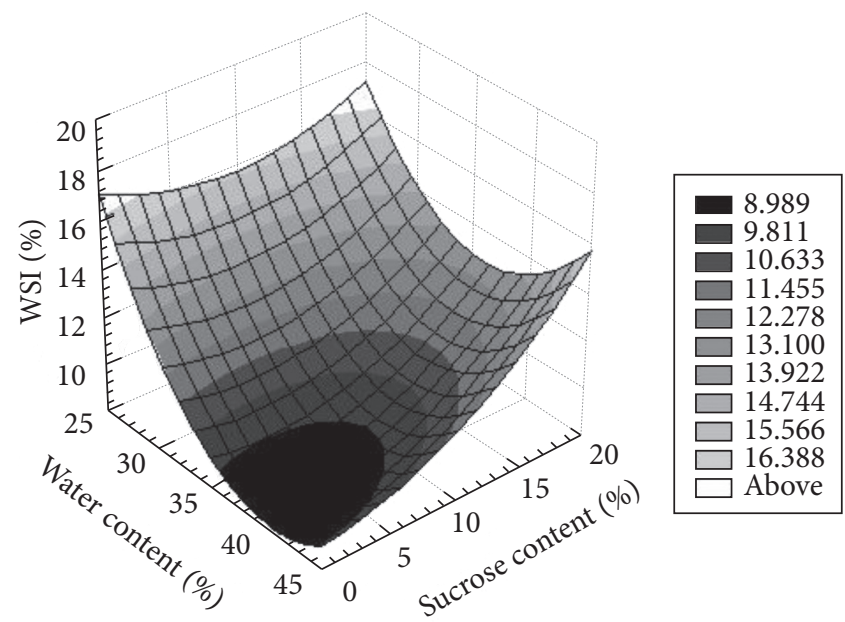

Figure 2. Effect of water and sucrose contents on the water solubility index (WSI) for rice extrudates.

a comparison of our experimental WSI data with those reported in the literature is difficult due to the differences in processing conditions and raw materials.

\subsection{Volumetric expansion index (VEI)}

Expansion phenomena have been known to be basically dependent on viscous and elastic properties of molten dough (BHATTACHARYA; CHOUDHURY, 1994). The effects of the independent variables on VEI are shown in Table 2 and Figure 3. Table 2 shows that the negative quadratic and the positive linear effects of sucrose were the most significant $(p \leq 0.001)$ for this response variable followed by the negative quadratic effect of the water content and by the negative effect of the interaction between water and sucrose contents $(\mathrm{p} \leq 0.01)$. The positive linear effect of water content was not significant $(p>0.05)$.

The measured VEI for rice flour extrudates ranged from 4.01, determined for samples extruded in presence of $30 \%$ water and $17 \%$ sucrose, to 4.66 , for the sample processed with $27.9 \%$ water and $10 \%$ sucrose. For some authors, high expansion indexes at low water contents are typical of extruded products from cereals (COULTER; LORENZ, 1991; DOGAN; KARWE, 2003). Before frying, the water content of the samples varied from 8 to $10 \%$, and after frying it varied from 4 to $6 \%$.

Starch gelatinisation is directly related to the physical properties of extruded products (DOGAN; KARWE, 2003). 
An increase in the sucrose content resulted in a decrease in starch gelatinisation and, consequently, in a decrease in the volumetric expansion. Fan, Mitchell and Blanshard (1996) observed a reduction in the expansion indexes of maize starch extrudates, as the contents of sucrose and fructose increased in similar levels to those used in the present work.

Some authors related the behaviour of VEI with WAI and WSI values. Higher WAI and lower WSI values, generally, indicate high gelatinisation process during extrusion. In the present work, one of the highest values of VEI (4.56) were found for the highest WAI value $\left(4.91 \mathrm{~g}^{\mathrm{g}} \mathrm{g}^{-1}\right)$ and the lowest WSI value (8.48\%).

\subsection{Bulk density (BD)}

The bulk density of extrudates before frying varied from $0.93{\mathrm{~g} . \mathrm{cm}^{-3}}^{-3}$, under the conditions of $27 \%$ water and $10 \%$ sucrose contents, to $0.98 \mathrm{~g} . \mathrm{cm}^{-3}$, under the conditions of $30 \%$ water and $17 \%$ sucrose contents. The regression coefficients in Table 2 showed that the positive quadratic and negative linear effects of the sucrose content had the most significant effect $(p \leq 0.001)$ on the $\mathrm{BD}$ of non-expanded extrudates before frying. The positive quadratic effect of water content was highly significant ( $\mathrm{p} \leq 0.01$ ), as well as the positive effect of the interaction between the two independent variables $(\mathrm{p} \leq 0.05)$. The negative linear effect of the water content was also significant $(\mathrm{p} \leq 0.05)$. The effect of the extrusion conditions on the extrudate density may also be observed in the three-dimensional surface plot in Figure 4. According to Case, Hannann and Schwartz (1992), as gelatinisation proceeded, the volume of extruded products increased and the bulk density decreased.

After frying, the extrudates showed bulk densities in the range of 0.19 and $0.22 \mathrm{~g} . \mathrm{cm}^{-3}$. The lowest density was obtained at $27.9 \%$ water and $10 \%$ sucrose. The highest value was observed under the processing conditions of $30 \%$ water and $17 \%$ sucrose, as well as under conditions of $35 \%$ water and $19.9 \%$ sucrose.

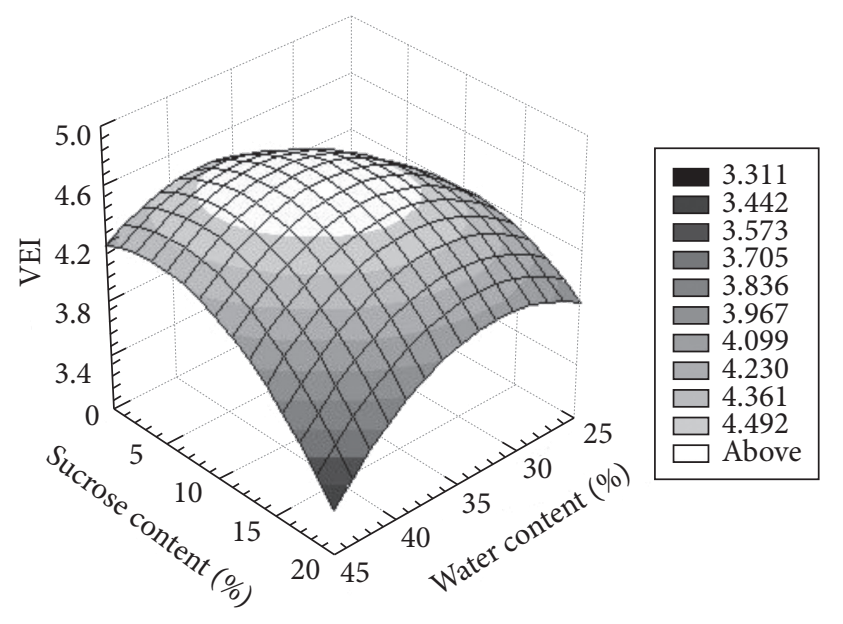

Figure 3. Effect of water and sucrose contents on the volumetric expansion index (VEI) for rice extrudates.
The response surface plot of Figure 5 shows a decrease in $\mathrm{BD}$ as the water content increased. The negative linear effect of water content was not significant on bulk density; whereas the negative linear effect of the sucrose content was highly significant $(\mathrm{p} \leq 0.001)$ on this dependent variable. The positive quadratic effect of the sucrose content followed by the positive quadratic effect of the water content was the most significant $(p \leq 0.001)$. The positive effect of the interaction between the two independent variables was also statistically significant $(\mathrm{p} \leq 0.01)$.

Heat absorbed during frying non-expanded extrudates contributed to the increase in the thermal input necessary to convert partially cooked starch granules by extrusion into a puffed structure typical of the extrusion process at high temperature, short time, and low water content. Temperature is one of the parameters that contributes to lower the density of starchy products (DOGAN; KARWE, 2003), and that imparts crispness, a characteristic highly appreciated by consumers.

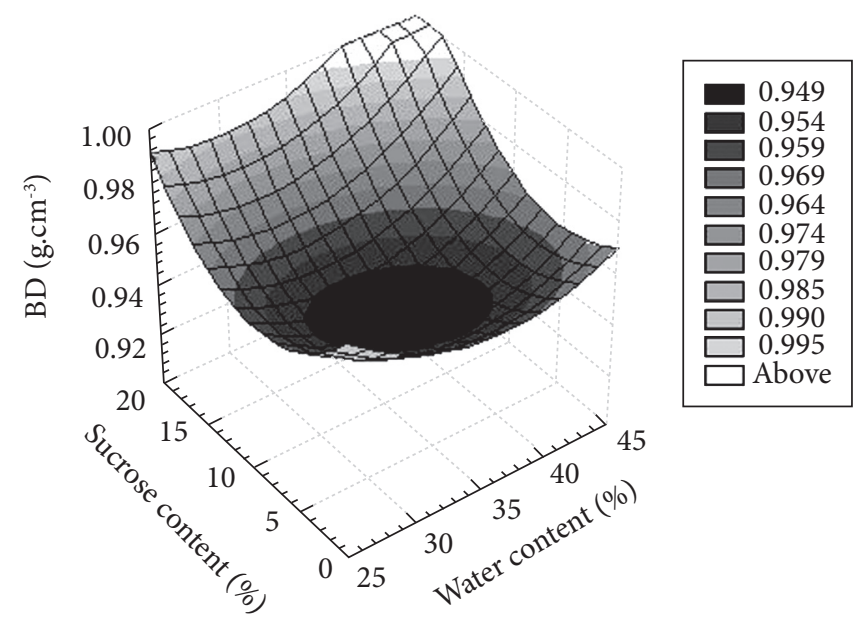

Figure 4. Effect of water and sucrose contents on the bulk density (BD) for rice extrudates before frying.

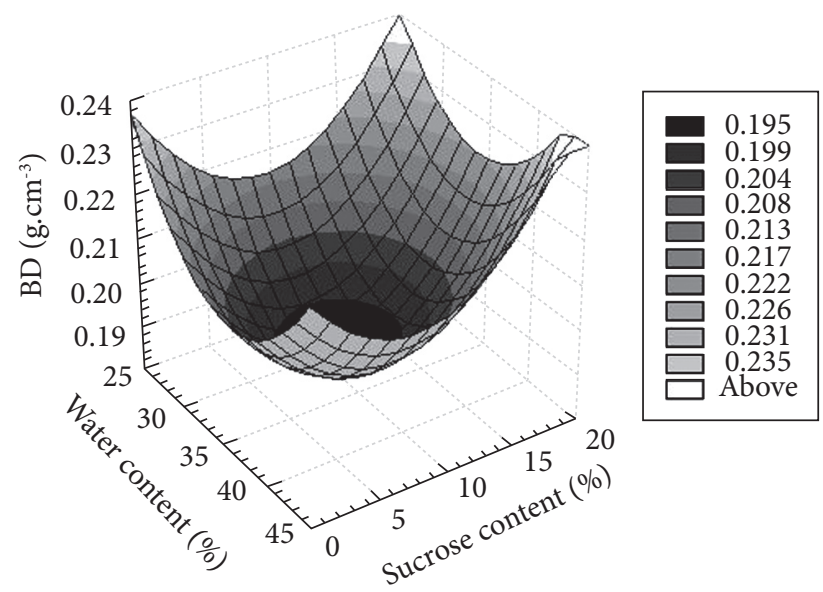

Figure 5. Effect of water and sucrose contents on the bulk density (BD) for rice extrudates after frying. 


\section{Conclusion}

The physicochemical properties of rice flour extrudates processed in a twin-screw extruder were dependent on the mixture composition. The water and sucrose contents had significant effects on the extrudate properties, and the sucrose content was the most important one. Water is known to function as a plasticiser for starch. In rice flour processing, the increase in the water content contributed to improve the water absorption capacity, which led to higher WAI and lower WSI values. The decrease in the water content led to higher shearing in extrusion processing, which favoured the increase in the amount of watersoluble molecules and resulted in samples with lower WAI and higher WSI values. The results showed that the increase in the sucrose content was associated with a decrease in WAI values and an increase in WSI values. Sucrose molecules have a low molecular weight, which contributed to an increase in the content of soluble solids and reduced the capacity of water as a plasticiser. The addition of sucrose at levels higher than $10 \%$ resulted in a decreased efficiency of the gelatinisation process. VEI and BD followed this trend, and lower VEI and BD values were determined. These properties were not found to be highly dependent on the water content. This behaviour may be explained by the drying and frying processes used.

\section{Acknowledgements}

The authors thank FAPERJ, CAPES, and CNPq for the financial support.

\section{References}

ANDERSON, R. A. et al. Gelatinization of corn grits by roll and extrusion cooking. Cereal Science Today, v. 14, n. 1, p. 4-12, 1969.

AKDOGAN, H. Pressure, torque and energy responses of a twin screw extruder at high moisture contents. Food Research International, v. 29, n. 5-6, p. 423-429, 1996.

BARRET, A. et al. Effect of sucrose on the structure, mechanical strength and thermal properties of corn extrudates. Carbohydrate Polymers, v. 26, n. 4, p. 261-269, 1995.

BHATTACHARYA, S.; CHOUDHURY, G. S. Twin-screw extrusion of rice flour: effect of extruder length-to-diameter ratio and barrel temperature on extrusion parameters and product characteristics. Journal of Food Processing and Preservation, v. 18, n. 5, p. 389-406, 1994.

BRYANT, R. J. et al. Functional and digestive characteristics of extruded rice flour. Cereal Chemistry, v. 78, n. 2, p. 131-137, 2001.

CARVALHO, C. W. P.; MITCHELL, J. R. Effect of sucrose on starch conversion and glass transition of non-expanded maize and wheat extrudates. Cereal Chemistry, v. 78, n. 3, p. 342-348, 2001.

CASE, S. E.; HANNANN, D. D.; SCHWARTZ, S. J. Effect of starch gelatinization on physical properties of extruded wheat and cornbased products. Cereal Chemistry, v. 69, n. 4, p. 401-404, 1992.

COULTER, L. A.; LORENZ, K. Extruded corn grits-quinoa blends: II. Physical characteristics of extruded products. Journal of Food Processing and Preservation, v. 15, n. 4, p. 231-242, 1991.

DESRUMAUX, A.; BOUVIER, J. M.; BURRI, J. Effect of free fatty acids addition on corn grits extrusion cooking. Cereal Chemistry, v. 76, n. 5, p. 699-704, 1999.
DING, Q. B. et al. The effect of extrusion conditions on the physicochemical properties and sensory characteristics of ricebased expanded snacks. Journal of Food Engineering, v. 66, n. 3, p. 283-289, 2005.

DING, Q. B. et al. The effect of extrusion conditions on the functional and physical properties of wheat-based expanded snacks. Journal of Food Engineering, v. 73, n. 2, p. 142-148, 2006.

DOGAN, H.; KARWE, M. V. Physicochemical properties of quinoa extrudates. Food Science and Technology International, v. 9, n. 2, p. 101-114, 2003.

FAN, J.; MITCHELL, J. R.; BLANSHARD, J. M. V. The effect of sugars on the extrusion of maize grits: I. The role of glass transition in determining product density and shape. International Journal of Food Science and Technology, v. 31, n. 1, p. 55-65, 1996.

GOMEZ, M. H.; AGUILERA, J. M. Changes in the starch fraction during extrusion cooking of corn. Journal of Food Science, v. 48, n. 2, p. 378-381, 1983.

GOMEZ, M. H.; AGUILERA, J. M. A physicochemical model for extrusion of starch. Journal of Food Science, v. 49, n. 1, p. 40-43, 1984.

GUHUA, M.; ALI, Z. S.; BHATTACHARYA, S. Twin-screw extrusion of rice flour without a die: Effect of barrel temperature and screw speed on extrusion and extrudate characteristics. Journal of Food Engineering, v. 32, n. 3, p. 251-267, 1997.

HAGENIMANA, A.; DING, X.; FANG, T. Evaluation of rice flour modified by extrusion cooking. Journal of Cereal Science, v. 43, n. 1, p. 38-46, 2006.

HSIEH, F. et al. Twin-screw extrusion of rice flour with salt and sugar. Cereal Chemistry, v. 70, n. 5, p. 493-498, 1993.

HSIEH, F.; PENG, I. C.; HUFF, H. E. Effect of salt, sugar and screw speed on processing and product variables of corn meal extruded with a twin-screw extruder. Journal of Food Science, v. 55, n. 1, p. 224-227, 1990.

ILO, S.; BERGHOFER, E. Kinetics of colour change during extrusion cooking of maize grits. Journal of Food Engineering, v. 39, n. 1, p. 73-80, 1999.

KADAN, R. S. et al. Texture and other physicochemical properties of whole rice bread. Journal of Food Science, v. 66, n. 7, p. 940-944, 2001.

KADAN, R. S.; BRYANT, R. J.; PEPPERMAN, A. B. Functional properties of extruded rice flours. Journal of Food Science, v. 68, n. 5, p. 1669-1672, 2003.

MASON, W. R.; HOSENEY, R. C. Factors affecting the viscosity of extrusion-cooked wheat starch. Cereal Chemistry, v. 63, n. 5, p. 436-441, 1986.

MEZREB, K. et al. Effect of sucrose on textural properties of corn and wheat extrudates. Carbohydrates Polymers, v. 64, n. 1, p. 1-8, 2006.

SEKER, M. Residence time distributions of starch with high moisture content in a single-screw extruder. Journal of Food Engineering, v. 67, n. 3, p. 317-324, 2005.

SINGH, N.; SMITH, A. C. A comparison of wheat starch, whole wheat meal and oat flour in the extrusion cooking process. Journal of Food Engineering, v. 34, n. 1, p. 15-32, 1997.

THYMI, S. et al. Structural properties of extruded corn starch. Journal of Food Engineering, v. 68, n. 4, p. 519-526, 2005. 